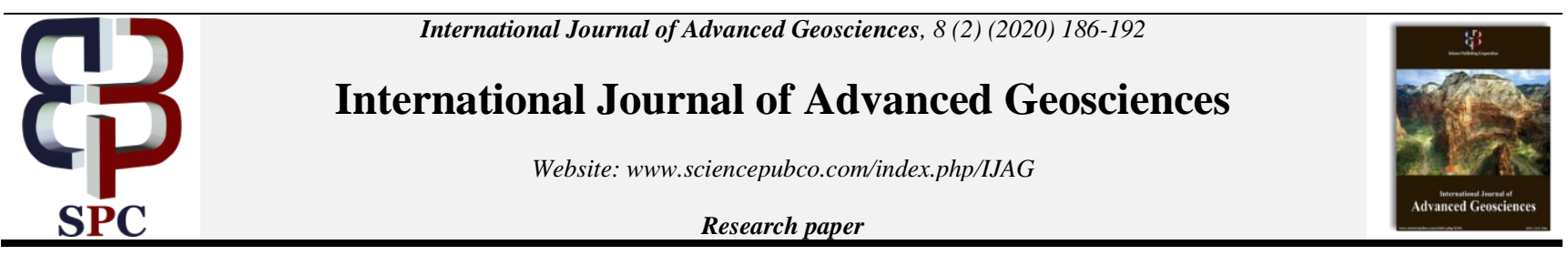

\title{
Compressive strength and water absorption of cement stabilized earth brick mixed with locust bean pod extract
}

\author{
Duru P. P ${ }^{1 *}$, Kaura J. M. ${ }^{1}$, Akin O. O. ${ }^{1}$, Raymond I. B ${ }^{1}$ \\ ${ }^{1}$ Department of Civil Engineering, Ahmadu Bello University, Zaria \\ *Corresponding author E-mail: paulduru80@yahoo.com
}

\begin{abstract}
This study presents the experimental investigation carried out on the compressive strength and water absorption properties of lateritic blocks stabilized with cement and locust bean pod extract. Tests were carried out in which different sample batches of cement blocks $(0.1$, $0.2,0.3,0.4$ and $0.5 \mathrm{~kg}$ ) were moulded and different sample batches of locust bean pod extract blocks $(50,100,133,150 \mathrm{and} 200 \mathrm{~g} / \mathrm{litre})$ were moulded and with both cement and locust bean pod moulded too. The compressive strength of the lateritic block samples were tested at 28 days. The results indicated that the cement with locust bean pod extract significantly increase the compressive strength of the lateritic block samples. This compressive strength increases as the amount of cement and locust bean pod extract was increased. This is a validation of the high possibilities of both cement locust bean pod extract being utilized as a binder in the production of blocks for low housing construction in developing areas of Nigeria.
\end{abstract}

Keywords: Laterite, Cement; Locust Bean Pod Extract; Compressive Strength; Water Absorption.

\section{Introduction}

Compressed stabilized soil blocks are building blocks which are made from raw soil mixed with an additive like cement, lime or even bitumen and then greatly compacted with a block press machine which results to a very dense, solid and low cost of building block. (Edgar 2015). These compressed soil blocks are mostly used for constructions of partition walls in rural and sometimes in the urban areas around the world.

One of the components of block is Sand which is a material of great demand in the construction industry due to its thought to be the most appropriate and plentiful fine aggregate used in the construction industry. Growing ecological contemplation are among other reasons besides being the only conventional fine aggregate that influence against supply of sand (Ata et al 2005). However a need to avoid exhaustion of this material is very important. Attention has been drawn to the used of low cost building materials in most cities of Nigeria in other to take care of this situation, sandcrete blocks are popularly known for use in partitioning for both commercial, residential, and industrial buildings (Agbede 2008). The demand for the sandcrete blocks have constantly kept the cost increasing and not affordable for rural residents which is of a high population in many parts of the country Nigeria. The high cost of sancrete blocks joined with the little strength properties of commercially available sancrete blocks imposes the need for alternatives low cost partitioning and walling materials.

Lateritic Soil blocks are produced by compacting a damp or wet natural Lateritic soil that has well sorted part of gravel, sand, silt and clay which are sometimes jointly referred to as laterite. Sometimes, this is stabilized with other material to improve it strength and durability as well. For thousands of years, earth is one of the oldest building material and has been used in the construction of shelters. Presently about one-third of the world's population continue to live in buildings made of earth materials (UN Habitat, 2008). Laterite which is one of this earth materials has been used widely for wall construction globally, especially in the developing countries (Ren et al 1995). Some of the geotechnical properties that influenced Lateritic soil are climate condition, drainage, geology, the nature of the parent rock and the degree or intensity of weathering or linearization of the parent rock. These influences likewise distinguish laterite from other soils that are developed in the temperate or cold regions. Some lateritic soils are believed to have been elated from their place of origin by agents of weathering such as wind or other actions, but majority of laterite which is used for road construction is possible to have been formed insitu. (Aginam et al 2015)

Due to increased agricultural and industrial activities across the globe, there has been significant increase in agricultural and industrial wastes which brings about the pollution of the environment. Locust bean pods happened to be an agricultural waste which is one of the agent of pollution if not properly abated. Today researchers are going into recycling of waste in the stabilization of soil for both building and road construction. Literatures are also available on modification for soil improvement, with these in mind, the need for sustainable production of block can be solved using locust bean pod extract on cement admixed blocks. 


\section{Review of similar studies}

Aguwa (2010), in an experiment on the Performance of Laterite-Cement Blocks as Walling Units in Relation to Sandcrete Blocks. An A2-6 laterite conferring to the AASHTO classification system was alleviated with $0-10 \%$ cement content by weight of the soil at a constant interval of $2 \%$ to produce blocks. These blocks were formed, cured under laboratory conditions and subjected to compressive strength test at 7- 28 days of age at a constant interval of 7 days intervals. All the mentioned procedures was also performed in the production of sandcrete blocks. In conclusion, the study endorses the use of laterite cement blocks as walling materials due to it better engineering properties and economical benefit when related with the use of sandcrete blocks.

Raheem et al. (2012) carried out a research on comparative analysis of sandcrete hollow blocks and laterite interlocking blocks as walling elements and they concluded from their research that laterite interlocking blocks have better strength and are cheaper than sandcrete hollow blocks.

Umar et al (2017) on a research on the compressive strength of RHA Stabilized earth bricks mixed with locust bean pod extract, moulded Sample batches of RHA bricks and distinguished the mix by the quantity of locust bean pod extract used in their blends. At 7, 14 and 28 days, compressive strength of the samples were tested and the result reveals that the locust bean pod extract significantly increase the compressive strength of RHA bricks. This validates the high abilities of locust bean pod extract being adopted as a binder in production of bricks with RHA.

Kagonde et al. (2020) on the sustainability of lateritic soils from Garoua in the production of earth blocks, determined the technological behaviours of the stabilized samples of the lateritic blocks with cement and came up with a positive conclusion that the compressive strength values of the samples produced are within acceptable limits and are recommended for use in the production of low cost housing construction.

Akinyemi et al. (2020) used red earth, lateritic soils and quarry dust as alternatives building materials in block production. In conclusion of the experiment, the compressive strength determined showed that the use of quarry dust and lateritic soil and the use of red earth and quarry dust had a good potential as a substitute when related to the adopting of river sand in the production of blocks for developing nations.

\section{Materials and methods}

\subsection{Materials}

a) Lateritic soil

The lateritic soil sample was collected by the method of disturbed sampling from an erosion site around Shika, Zaria, Kaduna state Nigeria. The soil sample was collected at depth of $1 \mathrm{~m}$ below the natural surface of the earth to avoid organic matter.

b) Water

Clean water from Ahmadu Bello University environs was used for the Lateritic soil block mix

c) Ordinary Portland cement

Ordinary Portland cement which was obtained at the open market in Zaria was used for this experiment

d) Locust Bean Pod

The locust bean tree is generally plentiful in the northern part of Nigeria. All the locust bean pods used in this research were gotten from villages in Niger State. Nigeria.

\subsection{Methods}

Production of the locust bean extract

The locust bean pods were bagged and conveyed to Samaru in Zaria local government, Kaduna State. They were grinded, weighed and further boiled in steel pots/container for about 20 minutes before it was left to cool down. The boiling method was used because there is increase in the solubility of the pods as the water temperature increases. Due to its low viscosity, the choice of using water as a solvent was implemented. After that period, the residue pods were removed by the process of sieving and then discarded. The liquid extract from the boiled pods which is dark purple in colour was collected and used for the mixes.

Laboratory test

The laboratory test conducted on the laterite soil for the purpose of characterisation comprises natural moisture content, specific gravity, atterberg limits and particles size distribution. These test were determined in accordance with BS 13771990 part 2.

Mixing and moulding

The mixing for the lateritic blocks of 230x110x 110mm are proportioned as shown in Table 1,2, 3 and 4 . Three iterations were made for every batch of lateritic block produced. About 50 compaction/blows was given for the production of every block using the moulding machine.

Table 1: Quantity of Material for Control Block Production

\begin{tabular}{lll}
\hline Batch I.D & Laterite $(\mathrm{kg})$ & Water $(\mathrm{kg})$ \\
\hline Control & 5 & 0.94 \\
\hline
\end{tabular}

Table 2: Quantity of Material for Cement Lateritic Block Production

\begin{tabular}{llll}
\hline Batch I.D & Laterite $(\mathrm{kg})$ & Cement $(\mathrm{kg})$ & Water $(\mathrm{kg})$ \\
\hline 01C & 4.90 & 0.10 & 0.94 \\
02C & 4.80 & 0.20 & 0.94 \\
03C & 4.70 & 0.30 & 0.94 \\
04C & 4.60 & 0.40 & 0.94 \\
05C & 4.50 & 0.50 & 0.94 \\
\hline
\end{tabular}

Table 3: Quantity of Material for Locust Bean Pod Extract Lateritic Block Production

\begin{tabular}{lll}
\hline Batch I.D & Laterite $(\mathrm{kg})$ & Locust B.P Extra. $(\mathrm{kg})$ \\
\hline 50 LBP & 5.00 & 0.94
\end{tabular}




\begin{tabular}{lll}
$100 \mathrm{LBP}$ & 5.00 & 0.94 \\
$133 \mathrm{LBP}$ & 5.00 & 0.94 \\
$150 \mathrm{LBP}$ & 5.00 & 0.94 \\
$200 \mathrm{LBP}$ & 5.00 & 0.94 \\
\hline
\end{tabular}

\begin{tabular}{llll} 
& \multicolumn{2}{l}{ Table 4: Quantity of Material for Cement +Locust Bean Pod Extract Lateritic Block Production } \\
\hline Batch I.D & Laterite $(\mathrm{kg})$ & Cement $(\mathrm{kg})$ & Locust B.P Extr. (kg) \\
\hline 01C50L & 4.90 & 0.10 & 0.94 \\
02C100L & 4.80 & 0.20 & 0.94 \\
03C133L & 4.70 & 0.30 & 0.94 \\
04C150L & 4.60 & 0.40 & 0.94 \\
05C200L & 4.50 & 0.50 & 0.94 \\
\hline
\end{tabular}

Compressive strength

Compressive strength of lateritic block is the measurement of its resistance to crushing load applied directly; this implies the maximum compressive load the block can transmit per unit area. This test was conducted in accordance with BS 1881, part 116 (1983).

Water absorption

Water absorption was conducted in accordance to BS EN 772-11. The block were oven dried at temperature of $35^{0}$ Celsius until a consistent mass was recorded, signifying a typical dried block after 28 days of curing at open room temperature. The mass of the specimen was measured and recorded. The $230 \times 110 \mathrm{~mm}$ bedside of the specimen was immersed to a depth of $5 \mathrm{~mm}$ in a constant head water bowl/tank for 10 minutes. The mass of the absorbed specimen was measured and recorded and the absorption of water was then determined

\section{Results and discussion}

\subsection{Result of chemical composition of OPC and locust bean pod extract}

Table 5: Oxide Composition of Cement and Locust Bean Pod Extract Used

\begin{tabular}{lll}
\hline Oxides & Cement $(\%)$ & Locust bean Pod Extract $(\%)$ \\
\hline $\mathrm{CaO}$ & 64.46 & 9.75 \\
$\mathrm{SiO}_{2}$ & 21.52 & 41.97 \\
$\mathrm{Al}_{2} \mathrm{O}_{3}$ & 5.29 & 10.21 \\
$\mathrm{Fe}_{2} \mathrm{O}_{3}$ & 3.95 & 5.82 \\
$\mathrm{Na}_{2} \mathrm{O}$ & - & 0.91 \\
$\mathrm{MgO}$ & 1.84 & 1.03 \\
$\mathrm{P}_{2} \mathrm{O}_{5}$ & - & 2.05 \\
$\mathrm{SO}_{3}$ & 1.50 & - \\
\hline
\end{tabular}

Table 4 shows the oxide composition of Cement and Locust bean pod extract. The oxide content of the cement compared with standard shows compliance to BS EN 197-1 (2011) and are within the range specified using Boque's equation. The $\mathrm{sum} \mathrm{Fe}_{2} \mathrm{O}, \mathrm{Al}_{2} \mathrm{O}_{3}$ and $\mathrm{SiO}_{2}$ of the Locust bean Pod Extract amounts to 58\% which satisfies the standard of 50\% minimum for class C natural pozollana based on ASTM C618.

\subsection{Index properties}

The natural soils were classified using the American Association of State Highway and Transportation Officials (ASSHTO, 1986) as A4(2). Using the Unified Soil Classification System, USCS (ASTM, 1992) the soil was classified as CL. The soil Sample has liquid limit, plastic limit and plasticity index of 29, 19 and $8 \%$ respectively. Summary of the geotechnical properties of the soil is given in Table 1 .

Table 6: Geotechnical Properties of the Natural Soils

\begin{tabular}{ll}
\hline Quantity & Sample \\
\hline Percentage passing sieve No 200 & 47.1 \\
Natural moisture content & 15.5 \\
Specific gravity(Gs) & 2.24 \\
Liquid limit (\%) & 29 \\
Plastic limit (\%) & 21 \\
Plasticity Index (\%) & 8 \\
AASHTO soil classification & A-4(2) \\
Unified soil classification system(USCS) & CL \\
Colour & Reddish brown \\
\hline
\end{tabular}

\subsection{Specific gravity}

Specific gravity is the ratio of the mass of unit volume of soil at a stated temperature to the mass of the same volume of gas-free distilled water at a stated temperature. The specific gravity was conducted for the lateritic soils. Specific gravity value for a soil is not normally used strictly for classification purposes, but are used in the calculation and interpretation of other test results such as hydrometer analysis. The lateritic soil sample has a specific gravity of 2.24 .

\subsection{Atterberg limits}

Atterberg limits tests are extensively used for classification of soils into groups on the basis of their position on the plasticity chart. Results obtained show that the soil sample is inorganic silt clay with low plasticity. From result the soil sample has a liquid limit of $29 \%$ 
and a plastic limit of $21 \%$. The plasticity index is a measure for determining the swelling potential of the soil. The soil sample has a plasticity index of $8 \%$.

\subsection{Particle size distribution}

The variation of the particle size distribution for the soil samples is shown in Figure 1. Results show that the soil sample fall within zone II in accordance to BS 882(1983). The hydrometer analysis conducted on the soil samples shows low amount clay fraction.

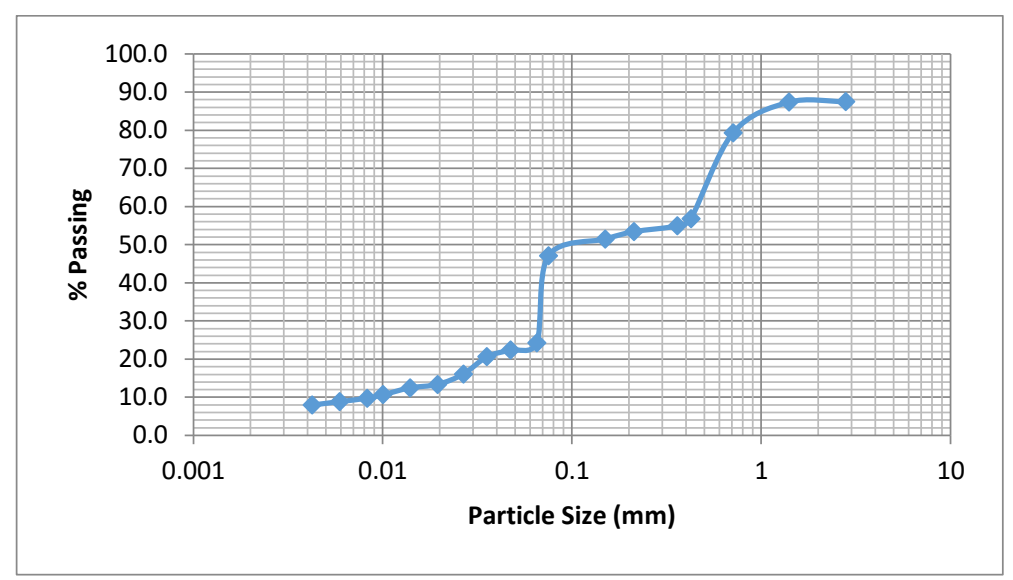

Fig. 1: Particle Size Distribution of the Soil Sample.

\subsection{Compaction test}

The compaction curve plotted showed that the soil sample recorded an MDD of $1.68 \mathrm{mg} / \mathrm{m}^{3}$ with an OMC of $18.8 \%$. The higher MDD of the soil sample is due to lower specific gravity of sample. Several literatures (Osinubi et al., 2015, Etim et al., 2017) reported that the specific gravity of soil affects it maximum dry density of compaction.

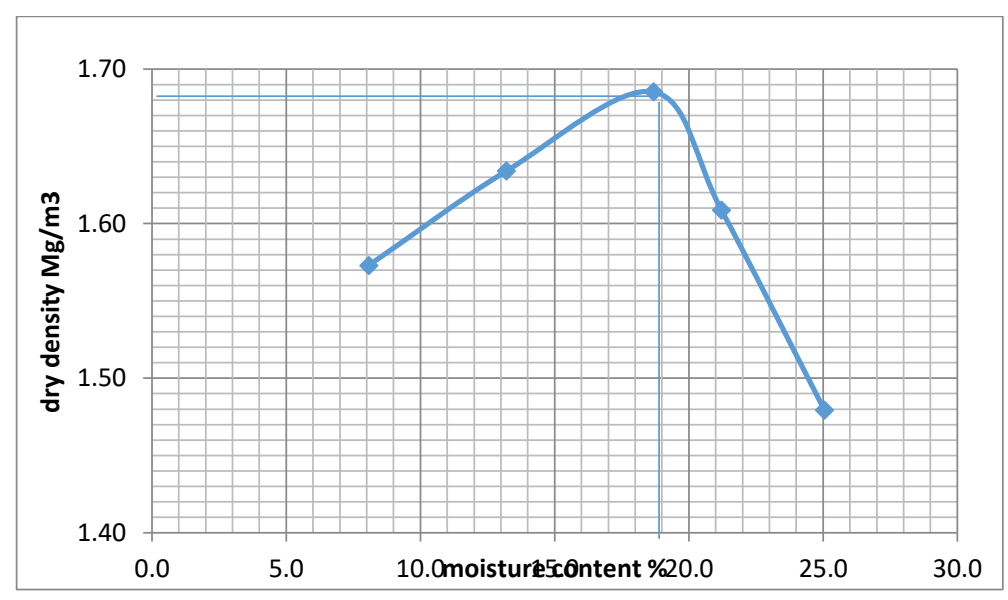

Fig. 2: Compaction Curves for Soil Sample.

\subsection{Compressive strength of lateritic blocks}

a) Compressive strength of lateritic blocks with locust bean pod extract

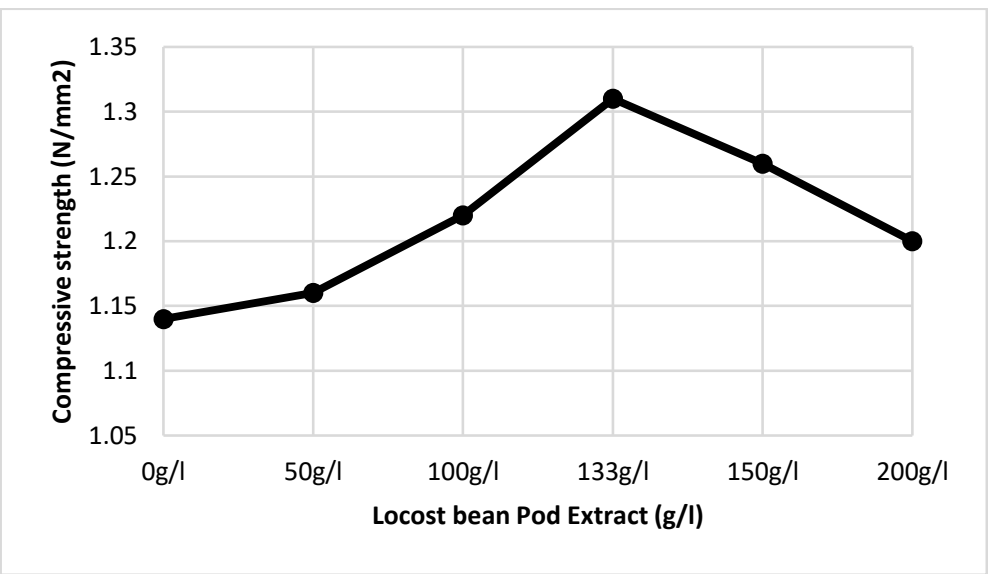

Fig. 3: Compressive Strength of Lateritic Block with Locust Bean Pod Extract. 
The effect of inclusion Locust bean pod extract on the 28 days compressive strength of lateritic block is shown in Figure 3, The strength of the control specimen was recorded as $1.14 \mathrm{~N} / \mathrm{mm}^{2}$ and $1.16 \mathrm{~N} / \mathrm{mm}^{2}, 1.22 \mathrm{~N} / \mathrm{mm}^{2}, 1.31 \mathrm{~N} / \mathrm{mm}^{2}, 1.26 \mathrm{~N} / \mathrm{mm}^{2}$ and $1.20 \mathrm{~N} / \mathrm{mm}^{2}$ at $50 \mathrm{~g} / \mathrm{l}$, $100 \mathrm{~g} / \mathrm{l}, 133 \mathrm{~g} / \mathrm{l}, 150 \mathrm{~g} / \mathrm{l}$ and $200 \mathrm{~g} / \mathrm{l}$ of locust bean pod extract respectively. The specimen with $133 \mathrm{~g} / \mathrm{l}$ has the highest compressive strength.

b) Compressive strength of lateritic blocks with cement

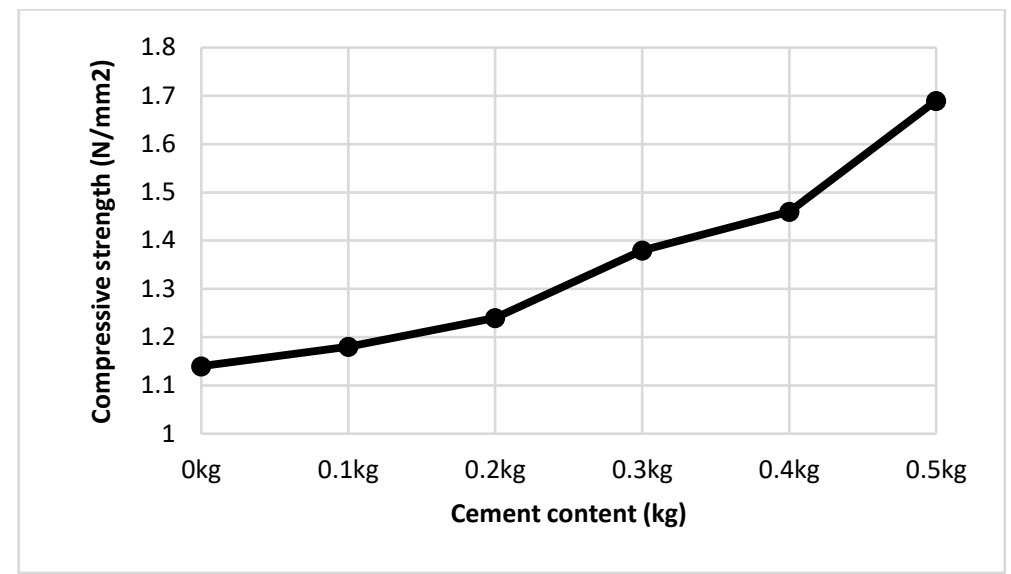

Fig. 4: Compressive Strength of Lateritic Block with Cement.

The effect of inclusion cement on the 28 days compressive strength of lateritic block is shown in Figure 4 . The compressive strength of the control specimen was recorded as $1.14 \mathrm{~N} / \mathrm{mm}^{2}$ and $1.18 \mathrm{~N} / \mathrm{mm}^{2}, 1.24 \mathrm{~N} / \mathrm{mm}^{2}$ and $1.38 \mathrm{~N} / \mathrm{mm}^{2}, 1.46 \mathrm{~N} / \mathrm{mm}^{2}$ and $1.69 \mathrm{~N} / \mathrm{mm}^{2}$ at $0.1 \mathrm{~kg}$, $0.2 \mathrm{~kg}, 0.3 \mathrm{~kg}, 0.4 \mathrm{~kg}$ and $0.5 \mathrm{~kg}$ of cement addition respectively. There is increase in compressive strength with increase in cement content in the lateritic block. The trend conform to Aguwa (2010) that increase in compressive strength with increase in cement content could be due to increased bonding within the aggregates of the blocks.

c) Compressive strength of lateritic blocks with cement and locust bean pod extract

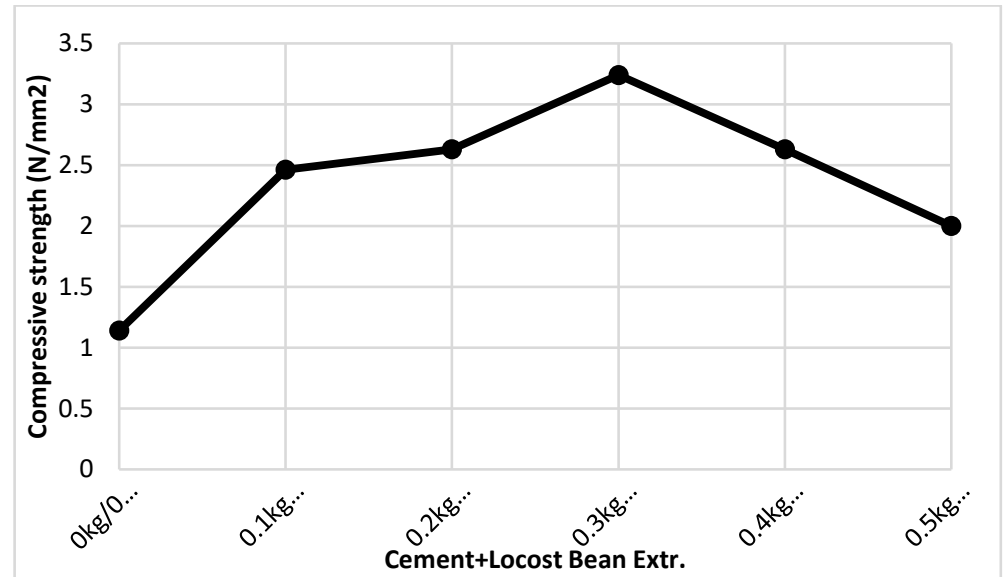

Fig. 5: Compressive Strength of Lateritic Block with Cement and Locust Bean Pod Extract.

The effect of inclusion cement on the 28 days compressive strength of lateritic block is shown in Figure 5, The strength of the control specimen was recorded as $1.14 \mathrm{~N} / \mathrm{mm}^{2}$ and $2.46 \mathrm{~N} / \mathrm{mm}^{2} 2.63 \mathrm{~N} / \mathrm{mm}^{2}, 3.24 \mathrm{~N} / \mathrm{mm}^{2}, 2.63 \mathrm{~N} / \mathrm{mm}^{2}$ and $2.0 \mathrm{~N} / \mathrm{mm}^{2}$ at $0.1 \mathrm{~kg} \& 200 \mathrm{~g} / 1$, $0.2 \mathrm{~kg} \& 150 \mathrm{~g} / \mathrm{l}, 0.3 \mathrm{~kg} \& 133 \mathrm{~g} / \mathrm{l}, 0.4 \mathrm{~kg} \& 100 \mathrm{~g} / \mathrm{l}$ and $0.5 \mathrm{~kg} \& 50 \mathrm{~g} / \mathrm{l}$ of cement plus locust bean pod extract respectively. There is increase in compressive strength till it gets to specimen with $0.3 \mathrm{~kg} \& 133 \mathrm{~g} / \mathrm{l}$ which has the highest compressive strength before having a decrease. The results show that the block produced satisfy the minimum of the 28days compressive strength of $2 \mathrm{~N} / \mathrm{mm}^{2}$ recommended by The Nigerian Building and Road Research Institute NBRRI (2006).

\subsection{Water Absorption of lateritic block}

Water absorption of lateritic block with Cement + Locust bean pod extract. 


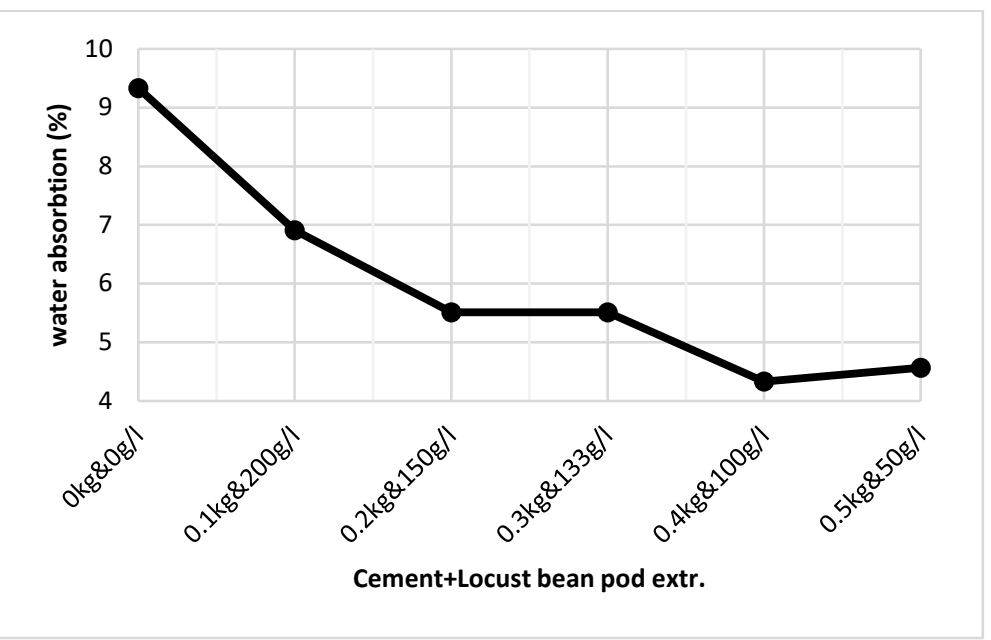

Fig. 6: Water Absorption of Lateritic Block with Cement + Locust Bean Pod Extract.

The effect of inclusion of cement + locust bean pod extract on the 28 days water absorption of lateritic block is shown in Figure 6 . There is decrease in water absorption of all specimen compared to the control specimen. This is as a result of the cement filling in the voids of the lateritic soil and also the contribution of the pozzolanic effect of the locust bean pod extract playing a vital within the soil block. The combination of both cement and locust bean pod extract has a water absorption value that is less than $15 \%$ which is the limit.

\section{Conclusion}

1) The sum of the $\mathrm{Fe}_{2} \mathrm{O}, \mathrm{Al}_{2} \mathrm{O}_{3}$ and $\mathrm{SiO}_{2}$ of the Locust bean Pod Extract amounts to $58 \%$ which satisfies the standard of $50 \%$ minimum for class $\mathrm{C}$ natural pozollana

2) The Soil Sample was classified as A-4(2) according to AASHTO and using USCS the soil fall under CL, Results obtained show that the soil sample is inorganic silt clay with low plasticity

3) There is increase on compressive strength of lateritic blocks when cement plus locust bean pod extract is induced in the production of lateritic blocks

4) There is decrease in water absorption of lateritic blocks when cement plus locust bean pod extract is induced in the production of lateritic blocks

\section{References}

[1] AASHTO (1986). Standard Specification for Transportation, Material and Methods of Sampling and Testing. 14th Edition. Amsterdam Association of State Highway and transportation officia Washington D.C.

[2] Agbede, I.O and Manasseh J. (2008). Use of cement sand admixtures in Laterite bricks production for low cost leonardo Electronic Journal of practices and technologies, 12 p. 163-174.

[3] Aginam C. H., Nwakaire C. and Nwajuaku A.I. (2013). Engineering Properties of Lateritic Soils from Anambra Central Zone, Nigeria; International Journal of Soft Computing and Engineering (IJSCE) ISSN: 2231-2307, Volume-4 Issue-6.

[4] Aguwa, J. I. (2010), Performance of Laterite-Cement Blocks as Walling Units in Relation to Sandcrete Blocks Leonardo Electronic Journal of Practices and Technologies ISSN 1583-1078 Issue 16, January-June 2010 p. 189-200.

[5] Akinyemi B. A., Elijah A., Oluwasegun A., Akpenpuun D. T., and Calony .O.,(2020), The use of red earth, lateritic soils and quarry dust as an alternative building materials in sandcrete blocks. Scientific African $7 \mathrm{e} 00263$ https://doi.org/10.1016/j.sciaf.2020.e00263.

[6] ASTM (1992). Annual Book of Standards. Vol. 04.08, American Society for Testing and Materials. Philadelphia.

[7] ASTM C618, (2008) Standard specification for coal fly ash and raw or calcined natural pozollan for use in concrete. American Society for testing and material International, West Coshohocken. PA

[8] Ata, O., Olusola K.O. and Aina, O.O.(2015). Factors Affecting poisons Ration of Laterized Concrete, Journal Sains Dan Teknology, EMAS, 15(2), pp.77-84.

[9] BS 1377 (1990), Method for Testing Soil for Civil Engineering Purposes, British Standard Institute, London.

[10] BS 1881 Part 116, Methods for Determining Compressive Strengths of Concrete Cubes. British Standard Institution, 2 park Street, London, 1983.

[11] BS 882:1983, Specification for aggregates from natural sources for concrete, British Standard Institution, London. 1983.

[12] BS EN 197-1, Cement, composition, specifications and conformity criteria for common cements European standard adopted by Bristish Standards Institution, 2011.

[13] BS EN 772-11, Methods for Determining of water absorption coefficient due to capillarity action for aggregate and masonry units, British Standard Institution, London. 2011.

[14] Edgar M. (2015). Production of compressed stabilized soil blocks (SSB), pocess analysis. Mzuzu University,Department of Land Management, Private Bag 201, Luwinga, Mzuzu 2. Malawi page 3.

[15] Etim R.K, Eberemu A.O and Osinubi K.J (2017) Stabilzation of Black Cotton Soil with Lime and Iron Ore Tailing Admixture. Journal of Transportation Geotechnics. Vol 10 pp 85-95. Elsevier Publishing Company https://doi.org/10.1016/j.trgeo.2017.01.002.

[16] Kagonbe B. P., Tsozue D., Nzukou A. N.,Basga S. P., Belinga R. E., Likiby B. and Ngos S.,(2020), Suitability of Lateritic Soil from Garoua (North Cameroon) in compressed stabilized Earth Blocks production for low cos housing construction, Journal of materials and environmental sciences. ISSN 2026-2508, Vol 11, Pg 658-669.

[17] NBRRI (2006) Nigerian Building and Road Research Institute, Interlocking Block Making Machine. NBRRI Newsletter Volume 1(1), pg 15-17

[18] Osinubi K. J, Yohanna, P and Eberemu, A. O. (2015) Cement Modification of Tropical Black Clay Using Iron Ore Tailing as Admixture. Journal of Transportation Geotechnics.Vol 5pp 35-49. Elsevier Publishing Company. https://doi.org/10.1016/j.trgeo.2015.10.001.

[19] Raheem, A. A., Momoh A. K. and Soyingbe, A. A (2012). Comparative analysis of sandcrete hollow blocks and laterite interlocking blocks as walling elements, International Journal of Sustainable Construction Engineering \& Technology (ISSN: 2180-3242) Vol 3, Issue 1, 2012. Pages 7988 
[20] Ren, K.B and Kagi, D.S. (1995), Upgrading the Durability of Mud Bricks by Impregnation, Build Build Environ, 30(3), pp.440. https://doi.org/10.1016/0360-1323(94)00056-X.

[21] Umar F.M, Habib .T and Ahmad .H (2017), Compressive Strength of RHA Stabilised Earth Bricks Mixed with Locust Bean Pod Extract, Journal of Applied Sciences and environmental sustainability 3(7): 155-128, 2017.

[22] UN Habitat (2008). Low- cost Sustainable Housing, Materials and Building Technology in Developing countries: UN Habitat. 